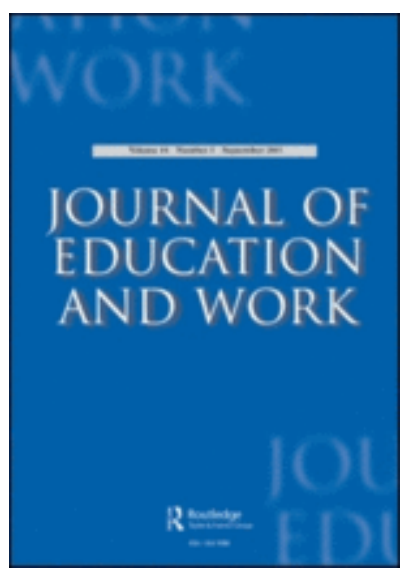

\title{
Learner identities in vocational education and training - from school to apprenticeship
}

\begin{tabular}{|r|l|}
\hline Journal: & Journal of Education and Work \\
\hline Manuscript ID & CJEW-2018-0185.R1 \\
\hline Manuscript Type: & Research Article \\
\hline Keywords: & Learner identity, vocational education, apprenticeship, positional identity \\
\hline & \\
\end{tabular}

\section{SCHOLARONE \\ Manuscripts}




\title{
Learner Identities in Vocational Education and Training - From School to Apprenticeship
}

\author{
Kristinn Hegna* \\ ${ }^{a}$ Department of Education, University of Oslo, Oslo, Norway \\ Kristinn Hegna \\ Associate Professor \\ Department of Education, Faculty of Educational Sciences \\ University of Oslo \\ PO Box Blindern \\ 0319 Oslo \\ Norway
}

Kristinn.Hegna@,iped.uio.no Twitter: @kristheg

ORCID: https://orcid.org/0000-0003-2462-2034

\begin{abstract}
Bio: Kristinn Hegna is associate professor in Sociology of Education at the Department of Education, Faculty of Educational Sciences at the University of Oslo. Her research interests includes the study of youth in a variety of settings, but above all; in education. Educational choice, reproduction of educational inequality, identity, subjectivities and citizenship in education, and gender segregation has been the topics of her most recent publications.
\end{abstract}


(199 words)

The aim of this paper is to describe changing learner identities and trajectories of identification that take place among vocational education and training (VET) apprentices in Norway. This paper describes 23 young, male VET students' learner identities in compulsory school (age 7-15) in comparison to their learner identities in VET apprenticeships (age 18-21), based on analyses of a set of biographical interviews about their schooling experiences. More specifically, the analysis describes changes in interviewees' learner identities in their transition from school to apprenticeship.

The analysis reveals that the narrative of being a student in school involved wounding educational experiences, such as negative student-teacher relationships, and feelings of failure and disengagement. At school, the participants' learner identities were positional identities created in the shadow of the figured world of school, leading the students to individualised withdrawal. The narratives of their apprenticeship was characterised by a sense of belonging, feelings of equality to peers, independence and adulthood. The 'adult working man' identity is a disguised learning identity, in that it breaks with the wounded learner identity of the 'failing student' and thereby creates opportunities for active learning for apprentices, both as individuals and members of communities of practice.

Keywords: Learner identity, vocational education, apprenticeship, positional identity, figured world

Word count: 8100 


\section{Learner Identities in Vocational Education and Training - From School to Apprenticeship}

\section{Introduction}

The upper-secondary vocational education and training (VET) system in Norway, as in Germany and Denmark, includes both work experience and apprenticeships, as both are important elements for developing trade-related skills. Workshop lessons and work placements, included in the first two years of in-school learning, and the apprenticeships, which take place during the third and fourth years of Norwegian VET, are considered instrumental in the development of informal skills and vocational identities related to workmanship, particularly for academically low-acheiving students. This article however, focusses on the changes and transformation of learner identities in vocational education and training.

Perspectives on learning and identity can highlight aspects of this transition process that are particularly important for school-aged youth as they mature and carve their paths in the world. In the sociocultural perspective on learning, learning trajectories are defined as processes whereby learning and identity formation mutually constitute each other.

Knowledge, social relations, institutional and structural positions are seen as integral parts of this process. In this paper, I describe young apprentices who successfully transitioned from school into apprenticeships. These apprentices share parallel stories of engagement and a joy for learning and development in their work position, in contrast to their previous school experiences, which are characterised by narratives of disengagement, failure, hardship and 'dropout'.

Vocational education and the related processes of learning described by, for instance, Lave and Wenger (1991), Colley et al. (2003) and Illeris (2010) are under pressure caused by 
the logic of the 'schooled society' (Baker 2014). Young people today experience this pressure as a demand to succeed in school, to realise their full potential, to be reflexive and responsible for their life choices, and they see themselves as individualised and autonomous (Illeris 2014). The current study analyses young apprentices' school biography interviews (West et al. 2007) and interpretes their stories about the transition from school into apprenticeships as narratives of change and development, in which the apprentices transform their learner identities and create opportunities for further learning. I argue that in cases of successful learner identity transformations, the workplaces in question offer the apprentices a learner identity that is well suited to ameliorating some of the damage from the 'wounding learner practises' (Wojecki 2007) that they experienced in school previously. This study expands insights from a community of practice perspective by adding a perspective on identity formation derived from sociocultural identity perspectives and youth research, and contributes to the sparse literature on youth's learner identities in VET.

\section{Wounded Learners, Learner Identities and Vocational Habitus in Transformative Learning Processes}

In their theory of situated learning, Lave and Wenger (1991) establish that learning is initiated through social practice; learners must participate in a social world, and simultaneously become a member of that social world. In other words, 'Learning thus implies becoming a different person with respect to the possibilities enabled by these systems of relations. To ignore this aspect of learning is to overlook the fact that learning involves the construction of identities' (Lave and Wenger 1991, 53, my emphasis). Learning a trade is therefore a process of 'production of persons' (58) and identity formation. In studies informed by this perspective, the vocational identity is explicitly (see for instance Klotz, Billet, and Winther [2014]) or implicitly described. An alternative angle however, is to focus the apprentice's identity as a learner. Analythically, a learner/learning identity can be 
described as 'the identity produced through or by learning' (Sefton-Green and Erstad 2013, 2) as often is the case in a community of practice perspective. In this context however, the learner identity is more specifically defined as 'the way they see themselves in the world and [...] how they interpret their participation and engagement with learning' (Wojecki 2007, 169). This optic turns the focus to "the identity acting as a precondition or context for learning and/or the kind of identity required by the learner to be able to learn as part of the learning process' (Sefton-Green and Erstad [2013, 2], with reference to Sinha [1999]).

In Willis's classic description of identities and learning in Learning to Labour (1999 [1978]), the working-class 'lads' reject classroom learning, fuelled by their strong identity as future working-class men. Thus, their identity as the 'lads' is a learner identity which affects their learning in school as well as their transition into work. Jackson's $(2006,2003)$ later description of the 'lads' portrays their learner identities as characterised by a fear of school failure and an alignment of school work to femininity, which in turn hinders their effort and compliance to school norms. These self-handicapping strategies exemplify how youth's selfunderstanding and identification with sociohistorical cultural identity categories can have consequences for their learning in a school setting.

Of relevance to the present study is how learner identities might shape or be affected by transitions; through education, or from education into work. Ecclestone (2007) claims that from a narrative identity perspective, such transitions can become problematic if a 'viable identity' (122) from one learning context does not transfer to another context. Existing positive learner identities might not translate into new settings without substantial and potentially stressful identity work or socialisation into the new circumstances.

Other researchers have highlighted the possible negative impact of former learner identities on further learning. In their research on 'wounded learners', Lange et al. (2015) and Olson (2015) describe how low-income, low-skilled adults recounted educational wounds 
from their previous schooling. Physical, psychological, intellectual and institutional wounds from their previous education included bullying, expectations of failure, low expectations from teachers, and the internalisation of verbal and physical messages from their academic failures, which the authors call a form of 'intellectual violence' (Lange et al. 2015, 92). In a study of wounded learners in VET, Wojecki (2007) found that their capacity for learning was not lacking, but their 'relationship to learning' had been wounded because these experiences were inherently 'linked with and attached to the individual's stories and "knowing" learning' (171). Wounded learners need to discharge, transform and 're-story' (Lange et al. 2015) their former contexts and identities.

A third perspective of interest for a study on changing learner identities is Colley et al.'s (2003) 'learning as becoming' perspective, which is based on Bourdieu's concepts of habitus and field. Rather than describing the transition to VET as either a continuation of or a forcible break with former learner identities, this perspective combines the past and the future by including the structure of family and social background with the agency of the individual in the term 'vocational habitus'. This perspective highlights how identities can be embodied predispositions for certain types of work, but that becoming a worker in a particular vocation still requires 'identity work' and a 'transformation of habitus' as part of an agentic process of orientation and construction of the vocational habitus (Colley et al. 2003, 489).

Learning and identity processes can be hard to disentangle. The concept 'learner identity' underlines how identities can act as a precondition or context for learning, and be required for the learner to be able to learn as part of the learning process (Sefton-Green and Erstad 2013), and this is the analythic perspective used in this study. Looking for the transitions or transformations of learner identities, with an open mind for the continuities as well as the discontinuities in individuals' experiences in school, could provide new insight 
into the intertwined processes of identification and learning both in school and in the transition from school to work (Illeris 2014).

\section{Symbolic and Positional Perspectives on Learning and Identity}

The transition from school to work, or from one educational institution to another, thus may imply changes in or transfers of learner identities between educational contexts. In this study, a situated learning perspective inspired by Lave and Wenger (1991), is complemented by a sociocultural perspective on identity formation in education to include the social and cultural contexts in which individuals’ participation and identity formation take place (Vågan 2011, 44). Vågan highlights two contributions that can potentially expand upon Lave and Wenger's perspective: Wortham's (2006) perspective of positional learner identities and Holland et al.'s (1998) 'figured worlds' concept. These analytic concepts add to the literature by highlighting differences in the structures of privilege and influence as well as the meanings, artefacts and familiar narratives of the particular loci where learning and identity formation may take place - that is, in school and in the workplace.

Wortham (2006) describes 'the joint emergence of social identification and academic learning' (emphasis added) in his book Learning Identity. By analysing classroom interactions, Wortham demonstrates how sociohistorical categories of identity - such as 'the unpromising boy' or 'the loud black girl' - come in to play in the classroom and define positions of importance for students' learner identities. In some cases, these models of identity were invoked by teachers, and the social identification of the given individuals was thus done to them. In other instances, 'The students themselves struggled with and partly shaped the models of identity that they came to inhabit' (Wortham 2006, 48). In his book, Wortham reveals how academic learning, knowledge and subject matter are interwoven with social identification and interpersonal struggles, ultimately explaining that the categories of 
identity partly originate from the subjects that are taught. However, the students' positioning and the positioning of students by their teachers in learning processes can also draw on other types of resources - for example, in non-academic learning contexts and learning trajectories outside the classroom.

The concept of 'figured worlds' (Holland et al. 1998; Holland and Lachicotte 2007) addresses both this active use of cultural resources in identity formation and learning and the taken-for-granted frame of meaning applied by individuals. Figured worlds are the 'socially and culturally constructed realm of interpretation in which particular characters and actors are recognised, significance is assigned to certain acts and particular outcomes are valued over others' (Holland et al. 1998, 52). In these figured worlds, identities are available as social and cultural products that are 'actively internalised as self-meanings' and 'serve as motivation for action' (Holland and Lachicotte 2007, 134). This perspective thus highlights how identities are rooted in discourse and narratives as well as in activities and practices by showing how cultural worlds are embedded and lived in social relations and interaction. Discourses, identities and artefacts 'originate outside their performers and are imposed upon people, through recurrent institutional treatments and within interaction' (Holland et al. 1998, 62), and these artefacts may gain force through their 'connection to their social and cultural contexts, [that is;] to the figured world' (63).

These perspectives guide the present study's analysis of learning trajectories, which is based on biographical interviews with young, male apprentices in electricity, carpentry, masonry, formwork and other trades about their experiences in schooling and training. Using these perspectives to supplement a focus on relations, skills, group identification and membership to a community (inspired by Lave and Wenger [1991]), this study focuses on changes in positioning and identification in the transition from school to apprenticeship. I argue that understanding the shift from the 'underperformer' identity or the 'school loser' 
identity at school to the 'working man' identity in an apprenticeship or in the workplace is crucial for understanding the successful transition through and completion of VET.

\section{Research Aim}

The aim of this paper is to analyse changes in the learner identities and trajectories of identification described by VET apprentices in Norway in the transition from school to work. Based on an analysis of school biography interviews, the paper discusses young VET students' naratives of learner identities in compulsory school (age 7-15) in comparison to their learner identities in VET apprenticeships (age 18-20). More specifically, the analysis describes changes in learner identities in the transition from school into apprenticeship, using a sociocultural perspective on learning and identity as the primary analytical framework.

The first part of the analysis focuses on narratives of learner identities in the figured world of schooling. In this section, I describe the wounding educational practices and the negative teacher interactions that position certain students as different, failing and disengaged learners. The second part of the analysis focuses on narratives of apprenticeship and describes how communities of practice and the figured world of work support positional identities that are equal, recognised, adult and independent. The analysis exposes the specific cultural identity at work in the apprentices' stories: the 'skilled adult working man', a positional identity that is very different than that of a student.

\section{Material and Methods}

This article is based on school biography interviews (West et al. 2007) conducted in 2013 and 2016 with 23 male students aged 18-21 who had just completed an upper-secondary vocational study programme or who were participating in an apprenticeship and working toward a trade certificate. The interviews were conducted as part of the study Safety-VET: Qualification and Social Inclusion in VET, which examined risk factors for VET dropout and 
successful completion processes against the odds, focussing among other things on social inclusion, the development of learner identities and competence. The Safety-VET study was a mixed methods study, including a longitudinal quantitative dataset following young people in Oslo through three data collections from age 14 to 17 (2006/2008/2010; for further details see Hegna [2013]). From a pool of about 100 consenting VET students of both genders in the quantitative dataset, only ten male and thirteen female (not included in the current study) informants in apprenticeship agreed to be interviewed in 2013 (aged 21 years). To expand the data on male apprentices, another five males were recruited through work places or the trade offices responsible for recruiting apprentices for different VET trades in Oslo (19 to 21 years of age). To complement the Oslo sample of relatively successful VET male apprentices, an additional eight male informants were recruited through a social project in a major city on the northwest coast of Norway (aged 18 years), in which disengaged youths were given the opportunity to complete an experience-based trade certificate for a lower degree than ordinary VET. The trade certificate (TC) project offered disengaged lower secondary school or first year VET students work-based learning four days per week and school-based learning one day per week. Thus, the sample could be described as a convenience sample where the aim of the sampling strategy was to recruit VET students with known risk factors for noncompletions (poor grades, parental low SES, school demotivation) who had made the successful transition to apprenticeship.

Of the twenty-three informants, seven were or had been apprentices as electricians and plane mechanics, while nine were carpenter masonry apprentices. Fifteen of these were from Oslo and one were from the TC project. Of the other informants from the TC project, three were wielder and sheet metal worker apprentices, two were specialising in warehouse logistics, one specialised in confectionery, and the last one in a programme for youth 
workers. The study programs and work placements are influenced by particular trade cultures, but in this context the general process of transition from school to work is focussed.

All fifteen of the male VET students included in the original Safety-VET study were born and raised in Oslo or in the outskirts of Oslo, whereas the eight informants recruited through the trade certificate project were born in a city on the northwest coast of Norway. Of the 23 informants, all except one were from working-class backgrounds and they had parents with no higher education. Thus, potential VET students from middle class or lower middle class backgrounds are not represented, in line with the sampling strategy of the study. Nine of the fifteen Oslo-based informants had two Norwegian-born parents, four were from immigrant families, one had a mixed background and one was adopted by Norwegian-born parents. All eight informants from the northwest coast had two Norwegian-born parents, reflecting the ethnic composition of the youth population at each geographical site.

\section{Data Collection and Analysis}

The school biography interviews described the participants' school experiences, including their learning experiences, their classmate and teacher experiences, their transitions between school levels, their transitions to work-based learning, and their experiences in the workplace, starting from their first day at elementary school. The participants also described their parents' role in their education. This method reflects the learning identity perspective of the study, and was selected because it provided insight into the narratives of identity processes and into the participants' development throughout their education. The interviews are therefore seen as recollections and reconstructions of the informants' schooling, and their stories should be understood and analysed as such. In their narratives, constructions of learning, relationships and identities were found. In constructing a narrative identity, continuity and coherence may be foregrounded by the informant at the expense of narratives 
of change and ruptures (Bamberg 2011), and the analyses of such interviews should take this into consideration.

All the interviews were conducted by a research assistant, except for two. Of these two interviews, one was conducted by the author and the other was conducted by both the author and the research assistant. The interviews were fully transcribed and coded using Nvivo $10^{1}$. All the participants' utterances that described experiences in school or with schooling; relationships with teachers, learning or school subjects; and homework were selected, as were their corresponding descriptions of their vocational education experiences, both in school and in the workplace. The transcriptions were coded in broad categories related to analytical themes, such as narratives of self-image and self-understanding, specific school subjects, relationships with fellow students and teachers, parental involvement in school, school-related tasks and homework, work-related tasks and duties, relationships with co-workers, future education and work. Particular focus was put on stories of underlying emotions like pride, sorrow or shame, as these stories were thought to be particularly linked to identification. Based on these themes, different learner identity categories emerged that were related to school and work. The material presented in this article represents quotes from 16 of the 23 informants.

\section{Wounding Learning Practices and the Figured World of Schooling}

Starting with the narratives of early schooling, the interviewees drew a striking contrast. They all told stories about good teachers, subjects they enjoyed, friendships and glimpses of the joy

1 NVivo is software that supports qualitative and mixed methods research, designed to organise, analyse and find insights in unstructured or qualitative data, such as interviews and open-ended survey responses. 
they felt from learning, reading and writing. However, there was almost always a 'but' in their stories. The trade certificate interviewees and more than half of the Safety-VET interviewees described their schooling in ways that fit well with the educational practices that Wojecki (2007) would categorise as 'wounding'. For example, the interviewees described institutional wounding practices related to their negative relationships with teachers who yelled at them, treated them unfairly, overlooked them, punished them unjustly or generally had low faith in their abilities. Jon received a lot of scolding in school, from his teacher, and was often sent to the principal's office. He said,

[The teacher] was always complaining, and I couldn't do anything right, and I wouldn't be able to get on in life if I continued like this [she said]. If I didn't have the energy to do my homework, I had to stay behind and do the homework after hours (Jon)

One of Jon's earliest memories from school was of picking up an enormous rock and wanting to throw it at the windows of the teachers' quarters. Like the other interviewees, he felt as if he was constantly being criticised.

The wounding effect of failing in school, and the consequential loss of motivation and spirit, is also overwhelmingly present in their stories. Fourteen of the interviewees described themselves as poor students who were sick of school: 'I didn't understand what I was supposed to do [with my homework]' (Alex); 'I couldn't write' (Benjamin); 'I used to cry in the morning' (Hussein); 'I didn't care about it...to learn' (Jon). For many of the interviewees, the constant negative feedback and feelings of failure affected the way they saw themselves and their future prospects. Teddy spelled it out clearly when he said, 'I'm put down. If your teacher is good, it's fun to learn actually. When negativity is all you get, you fall out. [Did you have any thoughts about the future, about future jobs?] No, it was completely dark. I wanted to become nothing.' For Max, such experiences affected his physical health:

Max: It was so difficult to bear... that everybody else could do it, but not me. 
Interviewer: Yes. What did you think about yourself at the time?

Max: Nothing. I just had to get through it.

Interviewer: Did you get any help with this?

Max: Yes. At the end of middle school, I was sent to counselling. [...] They found out that I had ADHD.

Interviewer: Did you have any physical symptoms [because of all the stuff at school]? Max: Yes, in a way. My neck was very tense. [Why?] Because I couldn't do it. I was constantly brooding over it. I got migraines. I had to start doing acupuncture (Max)

Chan Alexander and Erik also received medication for ADHD. Benjamin mentioned dyslexia, while Harry 'realised from the start' that he was not 'good at remembering stuff'. Andy had a speech impairment and was sent to a speech therapist; he was bullied, as was Jon. Meanwhile, Fahad described being the victim of discrimination. Lucas, Eddie and Jon were taken out of class to receive special tutoring, something which Lucas said made him feel 'special' in a negative way: 'I couldn't take it. I thought it was vile. All my friends were left in the classroom.' Simon describes himself as merely being present in lower-secondary school, rather than being an engaged student: 'I didn't skip. I was in school. But although I was there, I was not there to work. I was there to be present. [...] I came, and I wanted to go home right away.' Although the interviews revealed positive stories as well as stories of indifference to school, the 'failing student' identity was present to a large degree.

Some interviewees blamed abusive or 'poor' teachers, but most of the time, the interviewees related their stories to their own failures. Alex, Chan Alexander and Thomas (all Oslo apprentices) mentioned the Norwegian school ethos of 'taking responsibility for your own learning' as something they needed to relate to (see Dalland and Klette [2014]). In different ways, the interviewees individualised problems that could also have been interpreted as the result of cognitive impairments, educational institutions' symbolic power, teachers' failure or a lack of adapted or special education. In contrast to Willis's (1977) portrait of the 'lads' as a collective, oppositional force that resisted school values, these young men's stories 
disclose feelings of withdrawal, reduced self-esteem, and surrender. To a large extent, it seems that they were left on their own to grapple with the constant micro-attacks in their school environments. The figured world of schooling that they describe through their stories is not the figured world of schooling that their teachers and successful peers may have experienced, but rather one constructed in the shadow of it.

\section{Community, Meaning and Narratives of Skilfulness}

There is a striking contrast between the interviewees' 'wounded learner' stories and their stories about their apprenticeships. The interviewees described being part of a team and feeling like members of a community, qualities that resonate with the perspective of Lave and Wenger (1991). This was expressed by the interviewees both directly - 'I am part of the team' (Jacob, Andy, Teddy and Dahir) or 'it's like a small family' (Lucas) - and indirectly they felt 'safe and comfortable' around their workmates (Eddie); their workmates were 'very friendly' (Hussein, Besim, Jacob and Teddy); and they 'have a good sense of humour, joke a lot and talk bull' (Andy). The practices underlying these communities are related to building or achieving things together, but often, it is the symbolic meaning of other kinds of practices that stand out the most. For instance, many of the interviewees mentioned being invited out on the town to have a beer as a significant experience.

Harry made it clear that there were important differences between school and work in the social relations to their superiors: 'working with the grownups and feeling that they accept you', was constructed in contrast to his experiences at school, where 'the teacher can't choose a person. Here [at work] they are able to like every one of us. Rather than the teacher telling us "I can't like you, I can't like you"'. In the apprentices' stories, being part of the team was an important source for their motivation to work; they felt proud to be included in the working community. As Lave and Wenger (1991) highlight, to be accepted by the 
community is to be acknowledged as one of them, as a peer and as an equal. The positional identities in these narratives are fundamentally different from the hierarchies of studentteacher relationships - not in the actual structure, as apprentice-boss is by no means less hierarchical, but in that members are recognised and depend on each other.

Rather than describing the detachment and demotivation of schooling, the apprentices revealed that they craved challenges in their description of their work place learning. Hans expressed this sentiment as being tired of 'building garbage shacks' and repeating basic exercises. Simon drew a contrast between working at a company and attending school workshops: whereas the 'very boring' school workshop gave what he called a 'taste' of producing, and the teachers were 'almost as slack as the students', he described working for the company as giving 'insight'. More importantly,
Then you are let onto a team, right? You feel the atmosphere, the social setting. How things really work, apart from just producing. You realise that, damn, I like being here! [...] You can have a lot of fun at the same time because you are learning. When you get engaged, you are not going to quit. (Simon)

\begin{abstract}
While talking about their work, the participants used words such as 'interest', 'engagement' and 'the glow in me' (Fahad), as well as 'meaning [in what I do]' (Lucas). Being interested and engaged is a condition for learning, but in the narratives, these qualities seemed to also be the criteria for being a good apprentice:
\end{abstract}
You are supposed to show interest and engagement because that's when you learn the most, of course. [...] A boss should see you working and trying to find a solution, rather than just sitting on your ass and not knowing what to do. Better to ask for help if you need it, because then the boss will see that you are good and a clever guy. (Michael)
Being engaged contributes to their competence, both in a practical sense (e.g. you learn more), toward others (you present yourself as competent) and for yourself (representing


'glow', 'meaning' and skilfulness). For Harry, his newfound skilfulness also meant that he could compare himself to others with a successful result, and he commented on his transformation since his school days. At the time of the interview, Harry was working with one of the best students from his lower-secondary school class ('he was 18 times smarter than me') and imagined what his former classmates, who had known him as a failure in class would have said: “"What happened to him?” I've been thinking about that a lot, and I think it is great.' In these stories, the interviewees move forward into situations that enable them to enhance their skills and learning; this presents a sharp contrast from the withdrawal that characterised their school narratives.

Thus, an important source of identification was not only being knowledgeable and skilful, but also feeling knowledgeable and skilful. These excerpts from Andy and Besim reveal the new confidence the interviewees had developed. Andy described it as 'seeing that what the pros have taught you actually works'. Besim realised that '...if he makes a mistake, then you will make a mistake. So, it is better for you to come up with your own solutions that you think are right, the right things to do'. These are signs that a new confidence have grown in both Andy and Besim. Jon, an apprentice in cooking recruited from the trade certificate project, told his parents that he wanted to take on the task of making the dinner for his younger brother's confirmation party in the fall - a dinner which may include up to 20-50 people. Their newfound competence seems to have produced a certain hubris in some of the former school 'dropouts' recruited from the trade certification project. Lucas, who often cut classes and 'hit the wall' during the summer between eighth and ninth grade, 'had no idea' what he wanted to be after completing the 10 compulsory years in school. Two years later, he worked in a warehouse, specialising in logistics. Lucas said, 


\begin{abstract}
Lucas: Yeah! A lot of development. A lot! I can almost pick and choose... just jump on the train, and...what do I do now? There are a lot of possibilities. [...]

Interviewer: Where do you want to go?

Lucas: Up, in the management...I don't feel like sweeping the floor until I'm $60 \ldots$... feel like getting further ahead, climbing the ladder, and seeing what it looks like on the top floors.
\end{abstract}

Growing competence fosters a will to learn more and a willingness to train; increasing skills is a common thread in the stories. At school, the interviewees saw little meaning in the subjects they studied, had little experience to relate the knowledge to and had poor relationships with their teachers. Like for Simon, in terms of their learner identities in school, they were more like outcasts than students. In their apprenticeships, however, everything had changed: they were part of a team, they were more than willing to learn, they felt competent and they saw bright futures for themselves.

\title{
Identification with the 'Working Man' Identity
}

The material as a whole reveals strong similarity in the interviewees' narratives of their apprenticeships and the meaning it held for them - despite the various recruitment sites and trades that they come from. I interpret the underlying tone of pride in the stories as an indication that these cultural elements form the desired identity and the desired goal of identification. Apart from the feelings of competence and skilfulness described above, the interviewees also spoke with pride about their productivity, their will to endure hardship, and their feelings of maturity and independence.

Enduring the hardships that come with apprenticeship is a requirement of becoming a proper worker. The interviewees mentioned waking up early, which contrasted the common habit of arriving late to school: 'I had to get used to getting up at five in the morning. [...] The first couple of days, I remember being so nervous about coming in too late that I got up at f*ing four o'clock' (Jacob). They also described how they endured hard work and cold 
Both lower-secondary schooling and the anticipated transition to upper-secondary education coincide with adolescence, and for many interviewees, this was when disengagement from schooling started. In adolescence, building a sense of self is an important undertaking, one which young people are often left to process by themselves (Brannen and Nilsen 2002; Illeris 2014). A significant thread through the narratives of apprenticeship was related to finding a sense of self in adulthood rather than in youth.

Simon: I feel 10 times more grown up now. The kids - no, 'kids', hehe - I mean the friends I have that are in their third year [of GE] and who are my age now, I feel that I am outgrowing them, both in humour and generally as a person as well. It is probably because I am surrounded by adults all day.

Interviewer: How old are you now?

Simon: I am 18. [...] I feel so much more mature now than when I was in school, only 910 months ago.

Interviewer: Is that a good feeling, to outgrow your buddies?

Simon: Yes. Well, it is a good feeling to be adult. I start to see things differently. For the time being, like learning to save money, and you learn to be more independent. My friends are much more dependent on their parents. 
Growing up entails physical, mental and social changes, and it is not unusual to experience oneself as more mature as the years pass by. However, Simon's story is unusual because of the different pace he described for his development, compared to his friends', whom he described as 'kids' in school. He described himself as more mature, more adult, and someone who was learning to be more independent; he connected these sentiments to working life and to being in the company of adults.

Like Simon, the other interviewees also described their development toward maturity and adulthood. They experienced this in relation to their peers and shared a positive interpretation of how others see them differently now. Harry said, 'No one says right out that I have changed...but deep down I think they are a bit jealous that I have grown and started working.'

Stepping into the figured world of work gives new meaning to their practices, and the narratives of being adult and of being independent connect work to symbolic artefacts of the adult world of work: money, cars, drinking coffee, dirt and cold weather each play their part. Many interviewees mentioned their changing economic circumstances: having their own money, being able to administer their money sensibly, being able to save money and even being able to buy a car. For example, Teddy said, 'I have an Audi; they have a Ford. That says it all.' Symbolically, these artefacts contribute to a growing feeling of adulthood and independence.

These sentiments - feelings of recognition, the sense of being a peer, feelings of independence and a sense of adulthood - were also supported by the discovery that others trusted them more. For example, they were given tasks and trusted to work independently. This in turn changed their practices, such as 'not thinking about playing around as much' (Harry) on the one hand and on the other hand 'taking responsibility' (Simon, Chan Alexander, Dahir, Thomas, Michael, Hans, Isak, Phil and Lucas), 'making good choices [...] 
Jon: Now I'm in the kitchen with all the others, cooking and doing what the others do.

I'm not just asking 'What should I do now? What should I do now?'. I know what to do.

$[\ldots]$

Interviewer: What did they do to make you learn?

Jon: They showed me how to do it. I paid attention to what they were doing, and I asked questions.

Jon's story demonstrates how he now takes a more active role in his learning, and the ethos of 'being responsible for your own learning' that the school tried to convey to the students now resonates with him personally. Phil said that he learnt to 'do the tasks I am given, and to do them completely', while Max explained that he 'looked on [his workmates] as they were doing it, and I saw what needed to be done'. All the interviewees described their learning as more than imitation. They claimed a stronger agency and reflexivity in their apprenticeship role than they did as a student.

In summary, the apprentices described understanding themselves as skilled adult workers. They expressed feelings of belonging as peers and members of the worker community, they reported being acknowledged and seen as competent and skilful, they felt 
confident in their ability to produce and build, and they felt pride in enduring the hardship that comes with being a mature and independent worker. One important aspect of this identity construction is that it also involved elements that define the identity as a learner identity. This includes the increasing competence and the feeling that challenges can be met with creativity and ingenuity, or simply by being interested and motivated enough to ask a senior. Their wish to develop further and their joy for learning may be seen as surprising, given that many of the informants had been disinterested lower-secondary school students.

I argue not only that these factors are elements in a common narrative of a community of practice or of practical learning, but also that they together form a coherent whole which plays a crucial part in the VET apprentices' trajectory of identification. The skilful, adult working man is the (current) endpoint of this trajectory, which describes a total transformation whereby the identity of the working man replaces the identity of the student completely. This, however, does not entail a shift away from learning - in fact, quite the opposite. Because their learner identities were negatively or only loosely associated with the student role they enacted in school, their transformation into the 'working man' role allowed room for more, not less, learning than in the past. Describing the 'failing student' as a learner identity allowed us to see how identification with this identity category had consequences for what the young male informants felt they were 'allowed' and 'not allowed' to do at school. Being eager to learn is not one of those things, as is exemplified by Willis (1978) and Jackson (2006). The 'failing student' learner identity had serious detrimental effects to the young men's willingness and ability to learn. Their identification with the 'skilled, adult worker' identity allowed them to see themselves as competent and skilled, in contrast to their previous identification with the 'low achiever' profile, the 'disruptive boy' profile (Wortham 2006) or the 'lad' profile (Willis 1999 [1978]; Jackson 2006). 


\section{Discussion}

Through this analysis of the school experiences of 23 apprentices, I have shown that, for many, the narrative of being a student in school involves wounding educational experiences, such as negative student-teacher relationships, feelings of detachment from school and school subjects, and feelings of failure and disengagement. In such cases, students' learner identities in school develop as positional identities created in the shadow of the figured world of school, thereby leading the students to individualised withdrawal. The narrative of apprenticeship, in contrast, centres around feelings of belonging, equality with peers, pride, independence and being an adult. This identity of the adult working man is therefore a learning identity in disguise, in that it breaks with the former wounded learner identity and creates opportunities for active, reflexive learning for the apprentices, both as individuals and members of communities of practice.

These trajectories of identification (Wortham 2006) can be interpreted as examples of the identity perspective on transformative learning suggested by Illeris (2014). This perspective, in which transformative learning is defined as 'all learning which implies changes in the identity of the learner' (Illeris 2014, 40), opens up for including the social and structural context to the understanding of learning processes. While the transformation from an individualised wounded learner to an adult working man implies healing, development and maturation for the individual, the analysis also reveals the impact of individualisation in education, the power- and knowledge-structures inherent in schooling, the community of practice, and the figured world which combines masculinity, adulthood and work.

Previous analyses of individualisation in young, working-class men's transitions to the labour market have concluded that 'only socially privileged and educationally successful youths succeed in transforming their agency into self-reflexive projects' (Heinz 2009, 391). While it is important to acknowledge that young, low-skilled men's transitions to work have 
been increasingly difficult over the years (Smith 2009), it is also important not to underscore the self-reflexivity and transitions of the self (Giddens 1991) that these young men displayed throughout their life histories. As such, it seems fitting to relate these experiences to the notion of 'embedded individualisation' (Dawson 2012), where previously collective concerns or fears are privatised or 'subsidiarised' (Bauman 2008, 88) to a private level. The withdrawal from school and transition to apprenticeship therefore represent a 'fateful moment' (Giddens 1991, 112) at which point the individual biography needs reorientation (Thomson et al. 2003) and that creates opportunities through which individuals can reauthor their identities to support learning (Wojecki 2007, 169). The community and collectivity of the interviewees' workplace learning experiences and their learning identity transformations gave them the chance to escape the individualising forces of education, while at the same time maintaining their agency, autonomy and independence. This autonomy is simultaneously clearly embedded in classed and gendered embodied identities.

The 'working man' identity is offered to apprentices via the workplace only - not via school workshops. The authenticity of the context and the figured world of work is needed to 'interpellate' (Youdell 2006; Althusser 1971) the apprentice into the working man identity. In addition, the position of the adult worker is a position in a community of peers. On numerous occasions, the respondents provided clues about the importance of being positioned as a coworker, a colleague, an adult, a coffee-break colleague and a night-out-on-the-town buddy. The new positional identity in itself opens the individual up for learning opportunities that had previously been discredited by the wounded learner identity, which was characterised by feeling powerless and in a subdued position. In the figured world of school, the positional identity of the learner is defined in contrast to the teacher position. Through numerous wounding practices (Wojecki 2007), the interviewees' narratives of themselves as learners in school were further shaped as the negation of the 'official' learner position, in which they 
were not able to 'take responsibility for their own learning' as the Norwegian ethos is articulated (cf. Dalland and Klette 2014). In contrast, their narratives of their identity in the figured world of work reveal a correspondence between these two levels.

\title{
Conclusion
}

Identification with the figured world of work and the adult working man position is important for wounded learners to be able to learn and acquire new skills. This identification represents a break with their previous identification as failed students, in which learning and the acquisition of new skills were strongly associated with feelings of failure and detachment. Understanding the shift from the 'underperformer' identity or the 'school loser' learner identity at school to the 'working man' learner identity in apprenticeship is crucial for understanding the successful transition to and completion of VET.

\author{
This work was supported by the Norwegian Research Council under Grant \#ES477332. No \\ potential conflict of interest was reported by the author. The author wishes to thank Dimitra \\ Christidou, Sarah Irwin, Leif Lahn, Ingrid Smette and Kristoffer Vogt for valuable comments \\ to earlier drafts of this article.
}




\section{References}

Althusser, Louis. 1971. 'Ideology and ideological state apparatuses.' In Lenin and Philosophy, 170-86. London: Monthly Review Press.

Baker, David P. 2014. The schooled society: The educational transformation of global culture. Stanford, CA: Stanford University Press.

Bamberg, Michael. 2011. 'Who am I? Narration and its contribution to self and identity.' Theory \& Psychology 21 (1):3-24.

Bauman, Zygmunt. 2008. The art of life. Cambridge: Polity Press.

Brannen, Julia, and Ann Nilsen. 2002. 'Young people's time perspectives: from youth to adulthood.' Sociology 36 (3):513-37.

Colley, Helen, David James, Kim Diment, and Michael Tedder. 2003. 'Learning as becoming in vocational education and training: class, gender and the role of vocational habitus.' Journal of Vocational Education and Training 55 (4):471-98.

Dalland, Cecilie P., and Kirsti Klette. 2014. 'Work-plan heroes: Student strategies in lowersecondary Norwegian classrooms.' Scandinavian Journal of Educational Research 58 (4):400-23.

Dawson, Matt. 2012. 'Reviewing the critique of individualization:The disembedded and embedded theses.' Acta Sociologica 55 (4):305-19. doi: 10.1177/0001699312447634.

Ecclestone, Kathryn. 2007. 'An identity crisis? Using concepts of "identity","agency" and "structure" in the education of adults.' 39 (2):121-31. doi: 10.1080/02660830.2007.11661544.

Giddens, Anthony. 1991. Modernity and self-identity : self and society in the late modern age. Stanford, CA: Stanford University Press.

Hegna, Kristinn. 2013. 'Changing Educational Aspirations in the Choice of and Transition to Post-Compulsory Schooling-A Three-Wave Longitudinal Study of Oslo Youth.' Journal of Youth Studies 17 (5): 592-613.

Heinz, Walther R. 2009. 'Structure and Agency in Transition Research.' Journal of Education and Work 22 (5):391-404.

Holland, Dorothy, and William Lachicotte. 2007. 'Vygotsky, Mead, and the new sociocultural studies of identity.' The cambridge companion to vygotsky:101-35.

Holland, Dorothy, William Lachicotte, Debra Skinner, and Carole Cain. 1998. Identity and agency in cultural worlds. Cambridge, MA: Harvard University Press.

Illeris, Knud. 2010. The fundamentals of workplace learning: Understanding how people learn in working life. Oxford: Routledge.

- 2014. 'Transformative learning and identity.' Journal of Transformative Education 12 (2):148-63.

Jackson, Carolyn. 2003. 'Motives for "laddishness" at school: Fear of failure and fear of the 'feminine'.' British Educational Research Journal 29 (4):583-98.

-2006. Lads and ladettes in school. Gender and a fear of failure. Maidenhead: Open University Press.

Klotz, Viola Katharina, Stephen Billett, and Esther Winther. 2014. 'Promoting workforce excellence: formation and relevance of vocational identity for vocational educational training.' Empirical research in vocational education and training 6 (1):6.

Lange, Elizabeth A, Donna M Chovanec, Trudy Cardinal, Tania Kajner, and N Smith Acuna. 2015. 'Wounded learners: Symbolic violence, educational justice, and re-engagement of low-income adults.' Canadian Journal for the Study of Adult Education 27 (3):83104.

Lave, Jean, and Etienne Wenger. 1991. Situated Learning: Legitimate Peripheral Participation. Cambridge: Cambridge University Press. 
Olson, Kirsten. 2015. Wounded by school: Recapturing the joy in learning and standing up to old school culture. New York: Teachers College Press.

Sefton-Green, Julian, and Ola Erstad. 2013. 'Identity, Community and Learning Lives in the Digital Age.' In Identity, community, and learning lives in the digital age, edited by Ola Erstad and Julian Sefton-Green. Cambridge: Cambridge University Press.

Sinha, Chris. 1999. 'Situated selves: Learning to be a learner.' In Learning sites: Social and technological resources for learning, edited by Joan Bliss, Roger Säljö and Paul Light, 32-48. Oxford: Pergamon Press.

Smith, Douglas I. 2009. 'Changes in transitions: the role of mobility, class and gender.' Journal of Education and Work 22 (5):369-90.

Thomson, Rachel, Robert Bell, Janet Holland, Sheila Henderson, Sheena McGrellis, and Sue Sharpe. 2002. 'Critical Moments: Choice, Chance and Opportunity in Young People's Narratives of Transition.' Sociology 36 (2):335-54. doi: $10.1177 / 0038038502036002006$.

Vågan, André. 2011. 'Towards a sociocultural perspective on identity formation in education.' Mind, Culture, and Activity 18 (1):43-57.

West, Linden, Peter Alheit, Anders Siig Anderson, and Barbara Merrill. 2007. Using biographical and life history approaches in the study of adult and lifelong learning: European perspectives. Vol. 2, European Studies in Lifelong Learning and Adult Learning Research. Frankfurt: Peter Lang.

Willis, Paul. 1999 [1978]. Learning to labour: How working class kids get working class jobs. Aldershot: Ashgate.

Wojecki, Andrew. 2007. 'What's identity got to do with it, anyway?' Constructing adult learner identities in the workplace.' Studies in the Education of Adults 39 (2):168-82.

Wortham, Stanton. 2006. Learning identity: The joint emergence of social identification and academic learning. Cambridge: Cambridge University Press.

Youdell, Deborah. 2006. 'Subjectivation and performative politics-Butler thinking Althusser and Foucault: intelligibility, agency and the raced-nationed-religioned subjects of education.' British Journal of Sociology of Education 27 (4):511-28. 


\title{
Learner Identities in Vocational Education and Training - From School to Apprenticeship
}

\author{
Kristinn Hegna* \\ ${ }^{a}$ Department of Education, University of Oslo, Oslo, Norway \\ Kristinn Hegna \\ Associate Professor \\ Department of Education, Faculty of Educational Sciences \\ University of Oslo \\ PO Box Blindern \\ 0319 Oslo \\ Norway
}

Kristinn.Hegna@iped.uio.no Twitter: @kristheg

ORCID: https://orcid.org/0000-0003-2462-2034

\begin{abstract}
Bio: Kristinn Hegna is associate professor in Sociology of Education at the Department of Education, Faculty of Educational Sciences at the University of Oslo. Her research interests includes the study of youth in a variety of settings, but above all; in education. Educational choice, reproduction of educational inequality, identity, subjectivities and citizenship in education, and gender segregation has been the topics of her most recent publications.
\end{abstract}


(199 words)

Abstract

The aim of this paper is to describe changing learner identities and trajectories of identification that take place among vocational education and training (VET) apprentices in Oslo,-Norway. This paper describes 23 young, male VET students' learner identities in compulsory school (age 7-15) in comparison to their learner identities in VET apprenticeships (age 18-2021), based on analyses of a set of biographical interviews about their schooling experiences. More specifically, the analysis describes changes in interviewees' learner identities in their transition from school to apprenticeship.

The analysis reveals that the narrative of being a student in school involved wounding educational experiences, such as negative student-teacher relationships, and feelings of failure and disengagement. At school, the participants' learner identities were positional identities created in the shadow of the figured world of school, leading the students to individualised withdrawal. The narratives of their apprenticeship was characterised by a sense of belonging, feelings of equality to peers, independence and adulthood. The 'adult working man' identity is a disguised learning identity, in that it breaks with the wounded learner identity of the 'failing student' and thereby creates opportunities for active learning for apprentices, both as individuals and members of communities of practice.

Keywords: Learner identity, vocational education, apprenticeship, positional identity, figured world

Word count: 8002 


\section{Learner Identities in Vocational Education and Training - From School to Apprenticeship}

\section{Introduction}

The upper-secondary vocational education and training (VET) system in Norway, as in Germany and Denmark, includes both work experience and apprenticeships, as both are important elements for developing trade-related skills. The workshopsWorkshop lessons and work placements, which are completed duringincluded in the first two years of in-school learning, and the apprenticeships, which take place during the third and fourth years of Norwegian VET, are considered instrumental in the development of informal skills and vocational identities related to workmanship, particularly for academically low-acheiving students. This article however, focusses on the changes and transformation of learner identities in vocational education and training.

Perspectives on learning and identity can highlight aspects of this transition process that are particularly important for school-aged youth as they mature and carve their paths in the world. In the sociocultural perspective on learning, alearning trajectory istrajectories are defined as a processprocesses whereby learning and identity formation mutually constitute each other. Knowledge, social relations, institutional and structural positions are seen as integral parts of this process. In this paper, I describe young apprentices who successfully transitioned from school into apprenticeships. These apprentices share parallel stories of engagement and a joy for learning and development in their work position, in contrast to their previous school experiences, which are characterised by narratives of disengagement, failure, hardship and 'dropout'.

Vocational education and the related formsprocesses of learning processes described by, for instance, Lave and Wenger (1991), Colley et al. (2003) and Illeris (2010) are under 
pressure caused by the logic of the 'schooled society' (Baker 2014). Young people today experience this pressure as a demand to succeed in school, to realise their full potential, to be reflexive and responsible for their life choices, and they see themselves as individualised and autonomous (Illeris 2014). The current study analyses young apprentices' school biography interviews (West et al. 2007) and interpretes their stories about the transition from school into apprenticeships as narratives of change and development, in which the apprentices transform their learner identities and create opportunities for further learning. I argue that in cases of successful learner identity transformations, the workplaces in question offer the apprentices a learner identity that is well suited to ameliorating some of the damage from the 'wounding learner practises' (Wojecki 2007) that they experienced in school previously. The contrast between what I call the 'failing student' and the 'working man' learner identities also lies in the different potential that these identities offer in terms of managing the challenges of growing up. This study expands insights from a community of practice perspective by adding a perspective on identity formation derived from sociocultural identity perspectives and youth research, and contributes to the sparse literature on youth's learner identities in VET.

\section{Wounded Learners, Learner Identities and Vocational Habitus in Transformative Learning Processes}

In their theory of situated learning, Lave and Wenger (1991) establish that learning is initiated through social practice; individualslearners must participate in a social world, and simultaneously become a member of that social world. In other words, 'Learning thus implies becoming a different person with respect to the possibilities enabled by these systems of relations. To ignore this aspect of learning is to overlook the fact that learning involves the construction of identities' (Lave and Wenger 1991, 53, my emphasis). Learning a trade is therefore a process of 'production of persons' (58) and identity formation. In studies informed by this perspective, the vocational identity is explicitly (see for instance Klotz, 
Billet, and Winther [2014)]) or implicitly described. An alternative angle however, is to focus the apprentice's identity as a learner. Analythically, a learner/learning identity can be described as 'the identity produced thoughthrough or by learning' (Sefton-Green \& $\underline{\text { and }}$ Erstad $2013,2)$ as often is the case in a community of practice perspective. In this context however, the learner identity is more specifically defined as 'the way they see themselves in the world and $[\ldots]$ how they interpret their participation and engagement with learning' (Wojecki 2007, 169). This optic turns the focus to “-the identity acting as a precondition or context for learning and/or the kind of identity required by the learner to be able to learn as part of the learning process"process' (Sefton-Green \& and Erstad [2013, 2,], with reference to Sinha [1999-.].]).

In Willis's classic description of identities and learning in Learning to Labour (1999 [1978]), the working-class 'lads' reject classroom learning, fuelled by their strong identity as future working-class men. Thus, their identity as the 'lads' is a learner identity which affects their learning in school as well as their transition into work. Jackson's $(2006,2003) \underline{\text { later }}$ description of the lads'lads' portrays their learner identities as characterised by a fear of school failure and an alignment of school work to femininity, which in turn hinders their effort and compliance to school norms. These self-handicapping strategies exemplify how youth's self-understanding and identification with sociohistorical cultural identity categories can have consequences for their learning in a school setting.

Of relevance to the present study is how learner identities might shape or be affected by transitions; through education, or from education into work. Ecclestone (2007) claims that from a narrative identity perspective, such transitions can become problematic if a 'viable identity' (122) from one learning context does not transfer to another context. In constructing a narrative identity, continuity and coherence may be foregrounded by the informant at the expense of narratives of change and ruptures (Bamberg, 2011), and thus, existingExisting 
positive learner identities might not translate into new settings without substantial and potentially stressful identity work or socialisation into the new circumstances.

Other researchers have highlighted the possible negative impact of former learner identities on further learning. In their research on 'wounded learners', Lange et al. (2015) and Olson (2015) describe how low-income, low-skilled adults recounted educational wounds from their previous schooling. Physical, psychological, intellectual and institutional wounds from their previous education included bullying, expectations of failure, low expectations from teachers, and the internalisation of verbal and physical messages from their academic failures, which the authors call a form of 'intellectual violence' (Lange et al. 2015, 92). In a study of wounded learners in VET, Wojecki (2007) found that their capacity for learning was not lacking, but their 'relationship to learning' had been wounded because these experiences were inherently 'linked with and attached to the individual's stories and "knowing" learning' (171). Wounded learners need to discharge, transform and 're-story' (Lange et al. 2015) their former contexts and identities.

A third perspective of interest for a study on changing learner identities is Colley et al.'s (2003) 'learning as becoming' perspective, which is based on Bourdieu's concepts of habitus and field. Rather than describing the transition to VET as either a continuation of or a forcible break with former learner identities, this perspective combines the past and the future by including the structure of family and social background with the agency of the individual in the term 'vocational habitus'

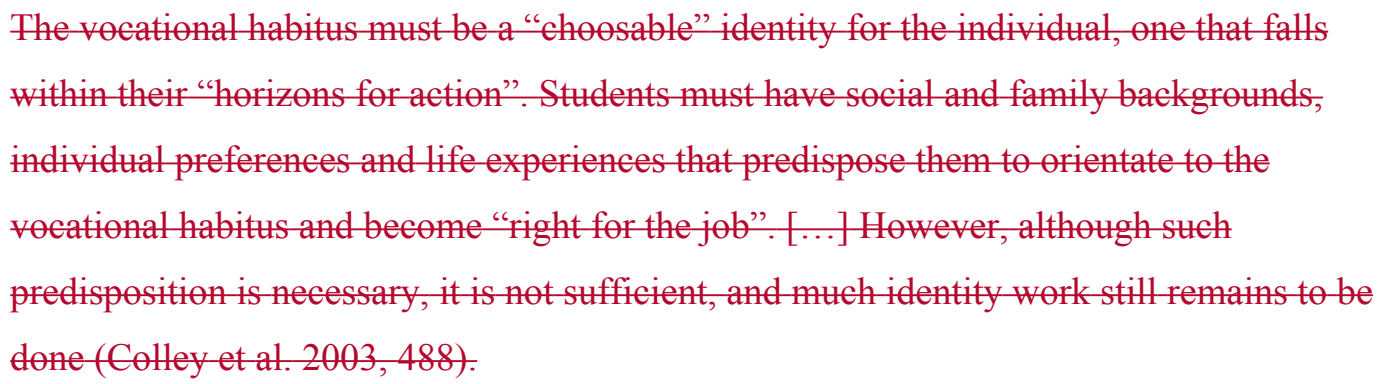


. This perspective highlights how identities can be embodied predispositions for certain types of work, but that becoming a worker in a particular vocation still requires 'identity work' and a 'transformation of habitus' as part of an agentic process of orientation and construction of the vocational habitus (Colley et al. 2003, 489).

Learning and identity processes can be hard to disentangle, and as these examples may have illustrated, the. The concept 'learner identity' underlines how identities can act as a precondition or context for learning, and be required for the learner to be able to learn as part of the learning process (Sefton-Green \&and Erstad 2013). In), and this article, anis the analythic perspective where a learner identity is seen as a preconditionused in this study. Looking for learning and as an identity that is reqired to be able to learn, will be utilized. Individuals' the transitions or transformations of learner identities might transition or transform through the course of schooling and vocational training. An, with an open mind for the continuities as well as the discontinuities in individuals' experiences in school, could provide new insight into the intertwined processes of identification and learning both in school and in the transition from school to work (Illeris 2014).

\section{Symbolic and Positional Perspectives on Learning and Identity}

The transition from school to work, or from one educational institution to another, thus may imply changes in or transfers of learner identities between educational contexts. To complement theIn this study, a situated learning perspective inspired by Lave and Wenger (1991), is complemented by a sociocultural perspective on identity formation in education eonsidersto include the social and cultural contexts in which individuals' participation and identity formation take place (Vågan 2011, 44). Vågan highlights two contributions that can potentially expand upon Lave and Wenger's perspective: Wortham's (2006) perspective of positional learner identities and Holland et al.'s (1998) 'figured worlds' concept. These analytic concepts eontribute to a perspective that joins activities and practicesadd to the 
literature by highlighting differences in the structures of privilege and influence as well as the meanings, artefacts and familiar narratives of the particular loci where learning and identity formation may take place-in this study - that is, in school and in the workplace.

Wortham (2006) describes 'the joint emergence of social identification and academic learning' (emphasis added) in his book Learning Identity. By analysing classroom interactions, Wortham demonstrates how sociohistorical categories of identity - such as 'the unpromising boy' or 'the loud black girl' - come in to play in the classroom and define positions of importance for students' learner identities. In some cases, these models of identity were invoked by teachers, and the social identification of the given individuals was thus done to them. In other instances, 'The students themselves struggled with and partly shaped the models of identity that they came to inhabit' (Wortham 2006, 48). In his book, Wortham reveals how academic learning, knowledge and subject matter are interwoven with social identification and interpersonal struggles, ultimately explaining that the categories of identity partly originate from the subjects that are taught. However, the students' positioning and the positioning of students by their teachers in learning processes can also draw on other types of resources - for example, in non-academic learning contexts and learning trajectories outside the classroom.

The concept of 'figured worlds' (Holland et al. 1998; Holland and Lachicotte 2007) addresses both this active use of cultural resources in identity formation and learning and the taken-for-granted frame of meaning applied by individuals. Figured worlds are the 'socially and culturally constructed realm of interpretation in which particular characters and actors are recognised, significance is assigned to certain acts and particular outcomes are valued over others' (Holland et al. 1998, 52). In these figured worlds, identities are available as social and cultural products that are 'actively internalised as self-meanings' and 'serve as motivation for action' (Holland and Lachicotte 2007, 134). This perspective thus highlights how identities 
are rooted in discourse and narratives as well as in activities and practices by showing how cultural worlds are embedded and lived in social relations and interaction. Discourses, identities and artefacts 'originate outside their performers and are imposed upon people, through recurrent institutional treatments and within interaction' (Holland et al. 1998, 62), and these artefacts may gain force through their 'connection to their social and cultural contexts, [that is;] to the figured world' (63).

These perspectives guide the present study's analysis of learning trajectories, which is based on biographical interviews with young, male apprentices in electricity, carpentry, masonry, formwork and other trades about their experiences in schooling and training. Using these perspectives to supplement a focus on relations, skills, group identification and membership to a community (inspired by Lave and Wenger [1991),]), this study focuses on changes in positioning and identification in the transition from school to apprenticeship. I argue that understanding the shift from the 'underperformer' identity or the 'school loser' identity at school to the 'working man' identity in an apprenticeship or in the workplace is crucial for understanding the successful transition through and completion of VET.

\section{Research Aim}

The aim of this paper is to analyse changes in the learner identities and trajectories of identification described by VET apprentices in Norway in the transition from school to work placement. Based on an analysis of school biography interviews, the paper discusses young VET students' naratives of learner identities in compulsory school (age 7-15) in comparison to their learner identities in VET apprenticeships (age 18-20). More specifically, the analysis describes changes in learner identities in the transition from school into apprenticeshipsapprenticeship, using a sociocultural perspective on learning and identity as the primary analytical framework. 
The first part of the analysis focuses on narratives of learner identities in the figured world of schooling. In this section, I describe the wounding educational practices and the negative teacher interactions that position certain students as different, failing and disengaged learners. The second part of the analysis focuses on narratives of apprenticeship and describes how communities of practice and the figured world of work support positional identities that are equal, recognised, adult and independent. The analysis exposes the specific cultural identity at work in the apprentices' stories: the 'skilled adult working man', a positional identity that is very different than that of a student. Given the specific makeup of 'the skilled adult worker' identity that is present in the VET apprentices' stories, their identification with this category represents a break with the 'failing student' identity from school. This break with their former wounded learner identity is what facilitates learning in a new context.

\section{Material and Methods}

This article is based on school biography interviews (West et al. 2007) conducted in 2013 and 2016 with 23 male students aged 18-21 who had just completed an upper-secondary vocational study programme or who were participating in an apprenticeship and working toward a trade certificate. These interviews belong to a larger body of interviews with male and female VET students in Norway. The interviews were conducted as part of the study Safety-VET: Qualification and Social Inclusion in VET, which examined risk factors for VET dropout and successful completion processes against the odds, focussing enamong other things on social inclusion, the development of learner identities, social inclusion and competence. In the context of the-The Safety-VET study, male VET students were recruited through various channels; ten informants were recruited through the database of was a mixed methods study, including a longitudinal quantitative survey on-dataset following young people in Oslo youththrough three data collections from age 14 to 17 (2006/2008/2010; for further details see Hegna [2013]). From a pool of about 100 consenting VET students of both 
genders in the quantitative dataset, only ten male and thirteen female (not included in the current study) informants in apprenticeship agreed to be interviewed in 2013 (aged 21 years), and-. To expand the data on male apprentices, another five males were recruited through work places or the trade offices responsible for recruiting apprentices for different VET trades in Oslo (19 to 21 years). An of age). To complement the Oslo sample of relatively

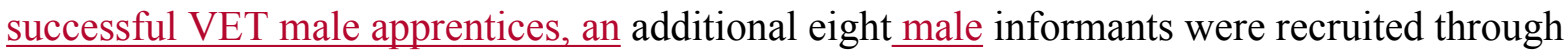
a social project in a major city on the northwest coast of Norway (aged 18 years), in which disengaged youths were given the opportunity to complete an experience-based trade certificate for a lower degree than ordinary VET. The trade certificate (TC) project offered disengaged lower secondary school or first year VET students work-based learning four days per week and school-based learning one day per week. Thus, the sample could be described as a convenience sample where the aim of the sampling strategy was to recruit VET students with known risk factors for non-completions (poor grades, parental low SES, school demotivation) who had made the successful transition to apprenticeship.

Of the twenty-three informants, seven were or had participated in the Electricity and Electronics study programme forbeen apprentices as electricians and plane mechanics, while nine had participated in the Building and Construction programme for carpenters and masons. Allwere carpenter masonry apprentices. Fifteen of these were from Osto based VET, exceptOslo and one of the carpenter apprentices who-were from the TC project. Of the other informants from the trade certificateTC project, three had participated in the Technical and Industrial Production programme for wielderswere wielder and sheet metal workersworker apprentices, two had participated in the Service and Transport study programmewere specialising in warehouse logistics, one had participated in the Restaurant and Food Processing programme for cooks and confectioners, and another had participated in the Healthcare for Children and Youth Developmentspecialised in confectionery, and the 
last one in a programme for youth workers. The study programs and work placements are influenced by particular trade cultures, but in this context the general process of transition from school to work is focussed.

All fifteen of the male VET students included in the original Safety-VET study were born and raised in Oslo or in the outskirts of Oslo, whereas the eight informants recruited through the trade certificate project were born in a city on the northwest coast of Norway. Of the 23 informants, all except one were from working-class backgrounds and they had parents with no higher education. Thus, potential VET students from middle class or lower middle class backgrounds are not represented, in line with the sampling strategy of the study. Nine of the fifteen Oslo-based informants had two Norwegian-born parents, four were from immigrant families, one had a mixed background and one was adopted by Norwegian-born parents. All eight informants from the northwest coast had two Norwegian-born parents, reflecting the ethnic composition of the youth population at each geographical site.

\section{Data Collection and Analysis}

The school biography interviews described the participants' school experiences, including their learning experiences, their classmate and teacher experiences, their transitions between school levels, their transitions to work-based learning, and their experiences in the workplace, starting from their first day at elementary school. The participants also described their parents' role in their education. This method reflects the learning identity perspective of the study, and was selected because it provided insight into the narratives of identity processes and into the participants' development throughout their education. The interviews wereare therefore seen as recollections and reconstructions of the informants' schooling, and their stories should be understood and analysed as such. In their narratives, constructions of learning, relationships and identities were found. In constructing a narrative identity, continuity and coherence may be foregrounded by the informant at the expense of narratives 
of change and ruptures (Bamberg 2011), and the analyses of such interviews should take this into consideration.

All the interviews were conducted by a research assistant, except for two. Of these two interviews, one was conducted by the author and the other was conducted by both the author and the research assistant. The interviews were fully transcribed and coded using Nvivo10 ${ }^{1}$. All the participants' utterances that described experiences in school or with schooling; relationships with teachers, learning or school subjects; and homework were selected, as were their corresponding descriptions of their vocational education experiences, both in school and in the workplace. The transcriptions were coded in broad categories related to analytical themes, such as narratives of self-image and self-understanding, specific school subjects, relationships with fellow students and teachers, parental involvement in school, school-related tasks and homework, work-related tasks and duties, relationships with co-workers, future education and work. Particular focus was put on stories of underlying emotions like pride, sorrow or shame, as these stories were thought to be particularly linked to identification. Based on these themes, different learner identity categories emerged that were related to school and work. The material presented in this article represents quotes from 16 of the 23 informants.

\section{Wounding Learning Practices and the Figured World of Schooling}

Starting with the narratives of early schooling, the interviewees drew a striking contrast. They all told stories-some about good teachers, subjects they enjoyed, friendships and glimpses of

1 NVivo is software that supports qualitative and mixed methods research, designed to organise, analyse and find insights in unstructured or qualitative data, such as interviews and open-ended survey responses. 
the joy they felt from learning, reading and writing. However, there was almost always a 'but' in their stories. The trade certificate interviewees and more than half of the Safety-VET interviewees described their schooling in ways that fit well with the educational practices that Wojecki (2007) would categorise as 'wounding'. For example, the interviewees described institutional wounding practices related to their negative relationships with teachers who yelled at them, treated them unfairly, overlooked them, punished them unjustly or generally had low faith in their abilities. JonJon received a lot of scolding in school, from his teacher, and was often sent to the principal's office. He said,

[The teacher] was always complaining, and I couldn't do anything right, and I wouldn't be able to get on in life if I continued like this [she said]. If I didn't have the energy to do my homework, I had to stay behind and do the homework after hours (Jon)

One of Jon's earliest memories from school was of picking up an enormous rock and wanting to throw it at the windows of the teachers' quarters. Like the other interviewees, he felt as if he was constantly being criticised.

The wounding effect of failing in school, and the consequential loss of motivation and spirit, is also overwhelmingly present in their stories. Fourteen of the interviewees described themselves as poor students who were sick of school: 'I didn't understand what I was supposed to do [with my homework]' (Alex); 'I couldn't write' (Benjamin); 'I used to cry in the morning' (Hussein); 'I didn't care about it...to learn' (Jon). For many of the interviewees, the constant negative feedback and feelings of failure affected the way they saw themselves and their future prospects. Teddy spelled it out clearly when he said, 'I'm put down. If your teacher is good, it's fun to learn actually. When negativity is all you get, you fall out. [Did you have any thoughts about the future, about future jobs?] No, it was completely dark. I wanted to become nothing.' For Max, such experiences affected his physical health:

Max: It was so difficult to bear... that everybody else could do it, but not me. 
Interviewer: Yes. What did you think about yourself at the time?

Max: Nothing. I just had to get through it.

Interviewer: Did you get any help with this?

Max: Yes. At the end of middle school, I was sent to counselling. [...] They found out that I had ADHD.

Interviewer: Did you have any physical symptoms [because of all the stuff at school]? Max: Yes, in a way. My neck was very tense. [Why?] Because I couldn't do it. I was constantly brooding over it. I got migraines. I had to start doing acupuncture (Max)

Chan Alexander and Erik also received medication for ADHD. Benjamin mentioned dyslexia, while Harry 'realised from the start' that he was not 'good at remembering stuff'. Andy had a speech impairment and was sent to a speech therapist; he was bullied, as was Jon. Meanwhile, Fahad described being the victim of discrimination. Lucas, Eddie and Jon were taken out of class to receive special tutoring, something which Lucas said made him feel 'special' in a negative way: 'I couldn't take it. I thought it was vile. All my friends were left in the classroom.' Simon describes himself as merely being present in lower-secondary school, rather than being an engaged student: 'I didn't skip. I was in school. But although I was there, I was not there to work. I was there to be present. [...] I came, and I wanted to go home right away.' Although the interviews revealed positive stories as well as ether-stories of indifference to school, the 'failing student' identity was present to a large degree.

Some interviewees blamed abusive or 'poor' teachers, but most of the time, the interviewees related their stories to their own failures. Alex, Chan Alexander and Thomas (all Oslo apprentices) mentioned the schøol's Norwegian school ethos of 'taking responsibility for your own learning' as something they needed to relate to (see Dalland and Klette [2014).]). In different ways, the interviewees individualised-eertain problems that could also have been interpreted as the result of cognitive impairments, educational institutions' symbolic power, teachers' failure or a lack of adapted or special education. In contrast to Willis's (1977) portrait of the 'lads' as a collective, oppositional force that resisted school values, these 


\section{Community, Meaning and Narratives of Skilfulness}

There is a striking contrast between the interviewees' 'wounded learner' stories and their stories about their apprenticeships. The interviewees described being part of a team and feeling like members of a community, qualities that resonate with the perspective of Lave and Wenger (1991). This was expressed by the interviewees both directly - 'I am part of the team' (Jacob, Andy, Teddy and Dahir) or 'it's like a small family' (Lucas) - and indirectly they felt 'safe and comfortable' around their workmates (Eddie); their workmates were 'very friendly' (Hussein, Besim, Jacob and Teddy); and they 'have a good sense of humour, joke a lot and talk bull' (Andy). The practices underlying these communities are related to building or achieving things together, but often, it is the symbolic meaning of other kinds of practices that stand out the most. fForFor instance, many of the interviewees; mentioned being invited out on the town to have a beer-was for instance mentioned as a significant experience.

Harry made it clear that there were important differences between school and work $\underline{\text { in }}$ the social relations to their superiors: 'working with the grownups and feeling that they accept you', was constructed in contrast to his experiences at school, where 'the teacher can't choose a person. Here [at work] they are able to like every one of us. Rather than the teacher telling us "I can't like you, I can't like you"'. In the apprentices' stories, being part of the team was an important source for their motivation to work; they felt proud to be included in the working community. As Lave and Wenger (1991) highlight, to be accepted by the 
community is to be acknowledged as one of them, as a peer and as an equal. The positional identities in these narratives are fundamentally different from the hierarchies of studentteacher relationships - not in the actual structure, as apprentice-boss is by no means less hierarchical, but in that members are recognised and depend on each other.

Rather than describing the detachment and demotivation of their schooling, the apprentices revealed that they craved challenges in their description of their work place learning. Hans expressed this sentiment as being tired of 'building garbage shacks' and repeating basic exercises. Simon drew a contrast between working at a company and attending school workshops: whereas the 'very boring' school workshop gave what he called a 'taste' of producing, and the teachers were 'almost as slack as the students', he described working for the company as giving 'insight'. More importantly,
Then you are let onto a team, right? You feel the atmosphere, the social setting. How things really work, apart from just producing. You realise that, damn, I like being here! [...] You can have a lot of fun at the same time because you are learning. When you get engaged, you are not going to quit. (Simon)

While talking about their work, the participants used words such as 'interest', 'engagement' and 'the glow in me' (Fahad), as well as 'meaning [in what I do]' (Lucas). Being interested and engaged is a condition for learning, but in the narratives, these qualities seemed to also be the criteria for being a good apprentice:
You are supposed to show interest and engagement because that's when you learn the most, of course. [...] A boss should see you working and trying to find a solution, rather than just sitting on your ass and not knowing what to do. Better to ask for help if you need it, because then the boss will see that you are good and a clever guy. (Michael)

Being engaged contributes to their competence, both in a practical sense (e.g. you learn more), toward others (you present yourself as competent) and for yourself (representing 
'glow', 'meaning' and skilfulness). For Harry, his newfound skilfulness also meant that he could compare himself to others with a successful result, and he commented on his transformation since his school days. At the time of the interview, Harry was working with one of the best students from his lower-secondary school class ('he was 18 times smarter than me') and imagined what his former classmates, who had known him as a failure in class would have said: "“What happened to him?" I've been thinking about that a lot, and I think it is great.' In these stories, the interviewees move forward into situations that enable them to enhance their skills and learning; this presents a sharp contrast from the withdrawal that characterised their school narratives.

Thus, an important source of identification was not only being knowledgeable and skilful, but also feeling knowledgeable and skilful. These excerpts from Andy and Besim reveal the new confidence the interviewees had developed. Andy described thatit as 'seeing that what the pros have taught you actually works'. Besim realised that '...if he makes a mistake, then you will make a mistake. So, it is better for you to come up with your own solutions that you think are right, the right things to do'. These are signs that a new confidence have grown in both Andy and Besim. Jon, an apprentice in cooking recruited from the trade certificate project, told his parents that he wanted to take on the task of making the dinner for his younger brother's confirmation party in the fall - a dinner which may include up to 20-50 people. Their newfound competence seems to have produced a certain hubris in some of the former school 'dropouts' recruited from the trade certification project. Lucas, who often cut classes and 'hit athe wall' during the summer between eighth and ninth grade, 'had no idea' what he wanted to be after completing the 10 compulsory years in school. He would rather have stayed home thanTwo years later, he worked in a warehouse, specialising in logistics, as he was doing two years later, at the time of the interview. Lucas said, 


\begin{abstract}
Lucas: Yeah! A lot of development. A lot! I can almost pick and choose... just jump on the train, and...what do I do now? There are a lot of possibilities. [...]

Interviewer: Where do you want to go?

Lucas: Up, in the management...I don't feel like sweeping the floor until I'm $60 \ldots$... feel like getting further ahead, climbing the ladder, and seeing what it looks like on the top floors.
\end{abstract}

Growing competence fosters a will to learn more and a willingness to train; increasing skills is a common thread in the stories. At school, the interviewees saw little meaning in the subjects they studied, had little experience to relate the knowledge to and had poor relationships with their teachers. Like for Simon, in terms of their learner identities in school, they were more like outcasts than students. In their apprenticeships, however, everything had changed: they were part of a team, they were more than willing to learn, they felt competent and they saw a-bright futurefutures for themselves.

\title{
Identification with the 'Working Man' Identity
}

The material as a whole reveals strong similarity in the interviewees' narratives of their apprenticeships and the meaning it held for them - despite the various recruitment sites and trades that they come from. I interpret the underlying tone of pride in the stories as an indication that these cultural elements form the desired identity and the desired goal of identification. Apart from the feelings of competence and skilfulness described above, the interviewees also spoke with pride about their productivity, their will to endure hardship, and their feelings of maturity and independence.

Enduring the hardships that come with apprenticeship is a requirement of becoming a proper worker. The interviewees mentioned waking up early, which contrasted the common habit of arriving late to school: 'I had to get used to getting up at five in the morning. [...] The first couple of days, I remember being so nervous about coming in too late that I got up at f*ing four o'clock' (Jacob). They also described how they endured hard work and cold 
Both lower-secondary schooling and the anticipated transition to upper-secondary education coincide with adolescence, and for many interviewees, this was when disengagement from schooling started. In adolescence, building a sense of self is an important undertaking, one which young people are often left to process by themselves (Brannen and Nilsen 2002; Illeris 2014). A significant thread through the narratives of apprenticeship was related to finding a sense of self in adulthood rather than in youth.

Simon: I feel 10 times more grown up now. The kids - no, 'kids', hehe - I mean the friends I have that are in their third year [of GE] and who are my age now, I feel that I am outgrowing them, both in humour and generally as a person as well. It is probably because I am surrounded by adults all day. Interviewer: How old are you now? Simon: I am 18. [...] I feel so much more mature now than when I was in school, only 910 months ago.

Interviewer: Is that a good feeling, to outgrow your buddies?

Simon: Yes. Well, it is a good feeling to be adult. I start to see things differently. For the time being, like learning to save money, and you learn to be more independent. My friends are much more dependent on their parents. 
Growing up entails physical, mental and social changes, and it is not unusual to experience oneself as more mature as the years pass by. However, Simon's story is unusual because of the different pace he described for his development, compared to his friends', whom he described as 'kids' in school. He described himself as more mature, more adult, and someone who was learning to be more independent; he connected these sentiments to working life and to being in the company of adults.

Like Simon, the other interviewees also described their development toward maturity and adulthood. They experienced this in relation to their peers and shared a positive interpretation of how others see them differently now. Harry said, 'No one says right out that I have changed...but deep down I think they are a bit jealous that I have grown and started working.'

Stepping into the figured world of work gives new meaning to their practices, and the narratives of being adult and of being independent connect work to symbolic artefacts of the adult world of work: money, cars, drinking coffee, dirt and cold weather each play their part. Many interviewees mentioned their changing economic circumstances: having their own money, being able to administer their money sensibly, being able to save money and even being able to buy a car. For example, Teddy said, 'I have an Audi; they have a Ford. That says it all.' Symbolically, these artefacts contribute to a growing feeling of adulthood and independence.

These sentiments - feelings of recognition, the sense of being a peer, feelings of independence and a sense of adulthood - were also supported by the discovery that others trusted them more. For example, they were given tasks and trusted to work independently. This in turn changed their practices, such as 'not thinking about playing around as much' (Harry) on the one hand and on the other hand 'taking responsibility' (Simon, Chan Alexander, Dahir, Thomas, Michael, Hans, Isak, Phil and Lucas), 'making good choices [...] 
Jon: Now I'm in the kitchen with all the others, cooking and doing what the others do.

I'm not just asking 'What should I do now? What should I do now?'. I know what to do.

$[\ldots]$

Interviewer: What did they do to make you learn?

Jon: They showed me how to do it. I paid attention to what they were doing, and I asked questions.

Jon's story demonstrates how he now takes a more active role in his learning, and the ethos of 'being responsible for your own learning' that the school tried to convey to the students now resonates with him personally. Phil said that he learnt to 'do the tasks I am given, and to do them completely', while Max explained that he 'looked on [his workmates] as they were doing it, and I saw what needed to be done'. All the interviewees described their learning as more than imitation. They claimed a stronger agency and reflexivity in their apprenticeship role than they did as a student.

In summary, the apprentices described understanding themselves as skilled adult workers. They expressed feelings of belonging as peers and members of the worker community, they reported being acknowledged and seen as competent and skilful, they felt 
confident in their ability to produce and build, and they felt pride in enduring the hardship that comes with being a mature and independent worker. One important aspect of this identity construction is that it also involved elements that define the identity as a learner identity. This includes the increasing competence and the feeling that challenges can be met with creativity and ingenuity, or simply by being interested and motivated enough to ask a senior. Their wish to develop further and their joy for learning may be seen as surprising, given that many of the informants had been disinterested lower-secondary school students.

I argue not only that these factors are elements in a common narrative of a community of practice or of practical learning, but also that they together form a coherent whole which plays a crucial part in the VET apprentices' trajectory of identification. The skilful, adult working man is the (current) endpoint of this trajectory, which describes a total transformation whereby the identity of the working man replaces the identity of the student completely. This, however, does not entail a shift away from learning - in fact, quite the opposite. Because their learner identities were negatively or only loosely associated with the student role they enacted in school, their transformation into the 'working man' role allowed room for more, not less, learning than in the past. Describing the 'failing student' as a learner identity allowed us to see how identification with this identity category had consequences for what the young male informants felt they were 'allowed' and 'not allowed' to do at school. Being eager to learn is not one of those things, as is exemplified by Willis (1978) and Jackson (2006). The 'failing student' learner identity had serious detrimental effects to the young men's willingness and ability to learn. Their identification with the 'skilled, adult worker' identity allowed them to see themselves as competent and skilled, in contrast to their previous identification with the 'low achiever' profile, the 'disruptive boy' profile (Wortham 2006) or the 'lad' profile (Willis 1999 [1978]; Jackson 2006). 


\section{Discussion}

Through this analysis of the school experiences of 23 apprentices, I have shown that, for many, the narrative of being a student in school involves wounding educational experiences, such as negative student-teacher relationships, feelings of detachment from school and school subjects, and feelings of failure and disengagement. In such cases, students' learner identities in school develop as positional identities created in the shadow of the figured world of school, thereby leading the students to individualised withdrawal. The narrative of apprenticeship, in contrast, centres around feelings of belonging, equality with peers, pride, independence and being an adult. This identity of the adult working man is therefore a learning identity in disguise, in that it breaks with the former wounded learner identity and creates opportunities for active, reflexive learning for the apprentices, both as individuals and members of communities of practice.

These trajectories of identification (Wortham 2006) can be interpreted as examples of the identity perspective on transformative learning suggested by Illeris (2014). This perspective, in which transformative learning is defined as 'all learning which implies changes in the identity of the learner' (Illeris 2014, 40), opens up for including the social and structural context to the understanding of learning processes. While the transformation from an individualised wounded learner to an adult working man implies healing, development and maturation for the individual, the analysis also reveals the impact of individualisation in education, the power- and knowledge-structures inherent in schooling, the community of practice, and the figured world which combines masculinity, adulthood and work.

Previous analyses of individualisation in young, working-class men's transitions to the labour market have concluded that 'only socially privileged and educationally successful youths succeed in transforming their agency into self-reflexive projects' (Heinz 2009, 391). While it is important to acknowledge that young, low-skilled men's transitions to work have 
been increasingly difficult over the years (Smith 2009), it is also important not to underscore the self-reflexivity and transitions of the self (Giddens 1991) that these young men displayed throughout their life histories. As such, it seems fitting to relate these experiences to the notion of 'embedded individualisation' (Dawson 2012), where previously collective concerns or fears are privatised or 'subsidiarised' (Bauman 2008, 88) to a private level. The withdrawal from school and transition to apprenticeship therefore represent a 'fateful moment' (Giddens 1991, 112) at which point the individual biography needs reorientation (Thomson et al. 2003) and that creates opportunities through which individuals can reauthor their identities to support learning (Wojecki 2007, 169). The community and collectivity of the interviewees' workplace learning experiences and their learning identity transformations gave them the chance to escape the individualising forces of education, while at the same time maintaining their agency, autonomy and independence. This autonomy is simultaneously clearly embedded in classed and gendered embodied identities.

The 'working man' identity is offered to apprentices via the workplace only - not via school workshops. The authenticity of the context and the figured world of work is needed to 'interpellate' (Youdell 2006; Althusser 1971) the apprentice into the working man identity. In addition, the position of the adult worker is a position in a community of peers. On numerous occasions, the respondents provided clues about the importance of being positioned as a coworker, a colleague, an adult, a coffee-break colleague and a night-out-on-the-town buddy. The new positional identity in itself opens the individual up for learning opportunities that had previously been discredited by the wounded learner identity, which was characterised by feeling powerless and in a subdued position. In the figured world of school, the positional identity of the learner is defined in contrast to the teacher position. Through numerous wounding practices (Wojecki 2007), the interviewees' narratives of themselves as learners in school were further shaped as the negation of the 'official' learner position, in which they 
were not able to 'take responsibility for their own learning' - as the Norwegian ethos is articulated (cf. Dalland and Klette 2014). In contrast, their narratives of their identity in the figured world of work reveal thea correspondence between these two levels.

\title{
Conclusion
}

Identification with the figured world of work and the adult working man position is important for wounded learners to be able to learn and acquire new skills. This identification represents a break with their previous identification as failed students, in which learning and the acquisition of new skills were strongly associated with feelings of failure and detachment. Understanding the shift from the 'underperformer' identity or the 'school loser' learner identity at school to the 'working man' learner identity in apprenticeship is crucial for understanding the successful transition to and completion of VET.

\author{
This work was supported by the Norwegian Research Council under Grant \#ES477332. No \\ potential conflict of interest was reported by the author. The author wishes to thank Dimitra \\ Christidou, Sarah Irwin, Leif Lahn, Ingrid Smette and Kristoffer Vogt for valuable comments \\ to earlier drafts of this article.
}




\section{References}

Althusser, Louis. 1971. 'Ideology and ideological state apparatuses.' In Lenin and Philosophy, 170-86. London: Monthly Review Press.

Baker, David P. 2014. The schooled society: The educational transformation of global culture. Stanford, CA: Stanford University Press.

Bamberg, Michael. 2011. 'Who am I? Narration and its contribution to self and identity.' Theory \& Psychology 21 (1):3-24.

Bauman, Zygmunt. 2008. The art of life. Cambridge: Polity Press.

Brannen, Julia, and Ann Nilsen. 2002. 'Young people's time perspectives: from youth to adulthood.' Sociology 36 (3):513-37.

Colley, Helen, David James, Kim Diment, and Michael Tedder. 2003. 'Learning as becoming in vocational education and training: class, gender and the role of vocational habitus.' Journal of Vocational Education and Training 55 (4):471-98.

Dalland, Cecilie P., and Kirsti Klette. 2014. 'Work-plan heroes: Student strategies in lowersecondary Norwegian classrooms.' Scandinavian Journal of Educational Research 58 (4):400-23.

Dawson, Matt. 2012. 'Reviewing the critique of individualization:The disembedded and embedded theses.' Acta Sociologica 55 (4):305-19. doi: 10.1177/0001699312447634.

Ecclestone, Kathryn. 2007. 'An identity crisis? Using concepts of "identity","agency" and "structure" in the education of adults.' 39 (2):121-31. doi: 10.1080/02660830.2007.11661544.

Giddens, Anthony. 1991. Modernity and self-identity : self and society in the late modern age. Stanford, CA: Stanford University Press.

Hegna, Kristinn. 2013. 'Changing Educational Aspirations in the Choice of and Transition to Post-Compulsory Schooling-A Three-Wave Longitudinal Study of Oslo Youth.' Journal of Youth Studies 17 (5): 592-613.

Heinz, Walther R. 2009. 'Structure and Agency in Transition Research.' Journal of Education and Work 22 (5):391-404.

Holland, Dorothy, and William Lachicotte. 2007. 'Vygotsky, Mead, and the new sociocultural studies of identity.' The cambridge companion to vygotsky:101-35.

Holland, Dorothy, William Lachicotte, Debra Skinner, and Carole Cain. 1998. Identity and agency in cultural worlds. Cambridge, MA: Harvard University Press.

Illeris, Knud. 2010. The fundamentals of workplace learning: Understanding how people learn in working life. Oxford: Routledge. . 2014. 'Transformative learning and identity.' Journal of Transformative Education 12 (2):148-63.

Jackson, Carolyn. 2003. 'Motives for "laddishness" at school: Fear of failure and fear of the 'feminine'.' British Educational Research Journal 29 (4):583-98.

-2006. Lads and ladettes in school. Gender and a fear of failure. Maidenhead: Open University Press.

Klotz, Viola Katharina, Stephen Billett, and Esther Winther. 2014. 'Promoting workforce excellence: formation and relevance of vocational identity for vocational educational training.' Empirical research in vocational education and training 6 (1):6.

Lange, Elizabeth A, Donna M Chovanec, Trudy Cardinal, Tania Kajner, and N Smith Acuna. 2015. 'Wounded learners: Symbolic violence, educational justice, and re-engagement of low-income adults.' Canadian Journal for the Study of Adult Education 27 (3):83104.

Lave, Jean, and Etienne Wenger. 1991. Situated Learning: Legitimate Peripheral Participation. Cambridge: Cambridge University Press. 
Olson, Kirsten. 2015. Wounded by school: Recapturing the joy in learning and standing up to old school culture. New York: Teachers College Press.

Sefton-Green, Julian, and Ola Erstad. 2013. 'Identity, Community and Learning Lives in the Digital Age.' In Identity, community, and learning lives in the digital age, edited by Ola Erstad and Julian Sefton-Green. Cambridge: Cambridge University Press.

Sinha, Chris. 1999. 'Situated selves: Learning to be a learner.' In Learning sites: Social and technological resources for learning, edited by Joan Bliss, Roger Säljö and Paul Light, 32-48. Oxford: Pergamon Press.

Smith, Douglas I. 2009. 'Changes in transitions: the role of mobility, class and gender.' Journal of Education and Work 22 (5):369-90.

Thomson, Rachel, Robert Bell, Janet Holland, Sheila Henderson, Sheena McGrellis, and Sue Sharpe. 2002. 'Critical Moments: Choice, Chance and Opportunity in Young People's Narratives of Transition.' Sociology 36 (2):335-54. doi: $10.1177 / 0038038502036002006$.

Vågan, André. 2011. 'Towards a sociocultural perspective on identity formation in education.' Mind, Culture, and Activity 18 (1):43-57.

West, Linden, Peter Alheit, Anders Siig Anderson, and Barbara Merrill. 2007. Using biographical and life history approaches in the study of adult and lifelong learning: European perspectives. Vol. 2, European Studies in Lifelong Learning and Adult Learning Research. Frankfurt: Peter Lang.

Willis, Paul. 1999 [1978]. Learning to labour: How working class kids get working class jobs. Aldershot: Ashgate.

Wojecki, Andrew. 2007. 'What's identity got to do with it, anyway?' Constructing adult learner identities in the workplace.' Studies in the Education of Adults 39 (2):168-82.

Wortham, Stanton. 2006. Learning identity: The joint emergence of social identification and academic learning. Cambridge: Cambridge University Press.

Youdell, Deborah. 2006. 'Subjectivation and performative politics-Butler thinking Althusser and Foucault: intelligibility, agency and the raced-nationed-religioned subjects of education.' British Journal of Sociology of Education 27 (4):511-28. 